\title{
Informacja o projekcie „INN@SE - Innovative Social Entrepreneurship with Youth Engagement", realizowanym w ramach programu Erasmus+, Partnerstwa Strategiczne na rzecz innowacji (2020-2022)
}

Przedsiębiorczość społeczną uznano za kluczowy element społecznej gospodarki rynkowej w UE. Przedsiębiorstwa społeczne przyczyniają się do powstawania i rozwoju nowych modeli biznesowych opartych na zasadach rynkowych, poszukując sposobów przyczyniania się do realizacji wartości gospodarczych i społecznych. Mają one również duży potencjał w zakresie opracowywania innowacji społecznych, mających na celu poprawę jakości życia, zaspokajanie nowych potrzeb lub restrukturyzację sektora publicznego. Niemniej, pojęcia „gospodarka społeczna” i „innowacje społeczne” są mało znane lub źle rozumiane i wydaje się, że rzadko uznaje się je za ważny czynnik w działalności gospodarczej, zwłaszcza w przypadku młodych ludzi. Z drugiej strony, start-upy społeczne napotykają więcej trudności w osiągnięciu stabilności ekonomicznej.

Odpowiedzią na te wyzwania jest projekt pt.: „INN@SE - Innovative Social Entrepreneurship with Youth Engagement", realizowany w latach 2020-2022 w Instytucie Prawa i Ekonomii Uniwersytetu Pedagogicznego w Krakowie. INN@SE jest międzynarodowym projektem badawczo-edukacyjnym ukierunkowanym na rozwój i wspieranie przedsiębiorczości społecznej, w szczególności młodzieży. Projekt jest współfinansowany przez Unię Europejską w ramach programu Erasmus+ Strategic partnerships for innovation. Uniwersytet Pedagogiczny jest jego liderem i koordynatorem, a w skład konsorcjum wchodzą także: ART-ER - Societa Consortile Per Azioni (Włochy), Organization for Social Innovation „ARNO” (Macedonia Północna), Desert Bloom for Training and Sustainable Development (Jordania).

Celem projektu jest przeprowadzenie badań w obszarze przedsiębiorczości społecznej młodzieży w różnych krajach biorących udział

1 Dr hab. Dorota Murzyn, Instytut Prawa i Ekonomii, Uniwersytet Pedagogiczny im. Komisji Edukacji Narodowej w Krakowie. 
w projekcie, tak by określić model wspierania przedsiębiorczości społecznej młodych ludzi, dostrzec słabe i mocne strony i zaprojektować system wsparcia zarówno w zakresie szkoleń dla przedsiębiorców społecznych już pracujących, jak i dla innych, którzy będą chcieli rozwijać swoją karierę zawodową w tym sektorze, a także zaprojektować innowacyjne usługi dla wsparcia rozwoju przedsiębiorczości społecznej młodzieży.

W celu rozwiązania problemu głównego i zrealizowania celów projektu, zaplanowano podjęcie badań wykorzystujących różne metody badawcze, począwszy od analizy teoretycznej, poprzez analizę ilościową obejmującą grupę młodych ludzi do 30 r.ż. i tzw. interesariuszy (CAWI), badania jakościowe ( $w$ tym desk research oraz badania sondażowe - pogłębiony wywiad częściowo standaryzowany oraz ankieta), a skończywszy na analizie SWOT. Ponadto, w celu określenia, jakie elementy innowacji można wprowadzić do istniejących usług wspierających przedsiębiorstwa społeczne i zdiagnozowania lokalnych potrzeb $\mathrm{w}$ tym zakresie, zaproponowano podejście wykorzystujące metody: service design, design thinking and co-design ( $w$ tym zorganizowanie grup fokusowych z lokalnymi interesariuszami).

Wyniki części z tych badań stały się podstawą do stworzenia innowacyjnych narzędzi edukacyjnych oraz rekomendacji dla twórców polityki. Projekt łączy zatem działalność badawczą z praktyką społeczno-gospodarczą, co jest jego kolejnym, bardzo ważnym celem. W tym wymiarze wyodrębniono następujące cele szczegółowe:

- upowszechnianie sposobu myślenia i umiejętności w zakresie przedsiębiorczości społecznej wśród młodych ludzi na szczeblu UE (oraz krajów partnerskich),

- promowanie przedsiębiorczości społecznej, ze szczególnym uwzględnieniem działań realizowanych przez, i dla młodych ludzi,

- podnoszenie świadomości wśród młodych ludzi jako aktywnych obywateli na temat wyzwań społecznych i środowiskowych oraz tego, w jaki sposób społeczna odpowiedzialność może im sprostać,

- zapewnienie początkującym, młodym przedsiębiorcom społecznym informacji i narzędzi na start.

Grupami docelowymi, czyli bezpośrednimi beneficjentami projektu są z jednej strony młodzi ludzie zainteresowani tematem przedsiębiorczości $\mathrm{i}$ innowacji społecznych, z drugiej natomiast - tzw. interesariusze, czyli pracownicy młodzieżowi, trenerzy, nauczyciele, trenerzy biznesowi i inni specjaliści (i powiązane organizacje) z sektora profit i non profit wspierający i promujący przedsiębiorczość wśród młodych ludzi.

Badania w ramach projektu INN@SE mają praktyczny i aplikacyjny charakter. Projekt opiera się na założeniu, że skuteczne podejście do przezwyciężenia wyzwań w obszarze rozwijania przedsiębiorczości społecznej może być reprezentowane przez metodologię otwartej innowacji opartej na międzysektorowym procesie współpracy. Partnerstwo w projekcie tworzą organizacje z krajów o różnym poziomie wiedzy na temat ekonomii 
i przedsiębiorczości społecznej (Polska, Włochy, Macedonia Północna, Jordania), reprezentujące sektory o różnym podejściu do tematu (szkolnictwo wyższe, instytuty badawcze, organizacje pozarządowe). Wszyscy partnerzy są wysoko wyspecjalizowani $\mathrm{w}$ działaniach związanych z pracą z młodymi ludźmi, szkoleniami, badaniami nad ekonomią społeczną i rozwojem start-upów, a różnorodna wiedza, doświadczenie i umiejętności, które każdy z partnerów wnosi do projektu, są gwarantem jakości i trwałości wspólnych wysiłków.

Do końca września 2021 roku osiągnięto już pewne rezultaty i zostały zrealizowane następujące działania:

1) Przeprowadzenie badania potrzeb wśród młodych ludzi i tzw. interesariuszy w czterech krajach biorących udział w projekcie oraz publikacja wyników tych badań w monografii wydanej przez Wydawnictwo Uniwersytetu Pedagogicznego ${ }^{2}$;

2) Zdiagnozowanie dobrych praktyk w zakresie przedsiębiorczości społecznej istniejących w Europie i na świecie oraz stworzenie bazy dobrych praktyk - ogólnodostępnego narzędzia, z którego mogą skorzystać młodzi ludzie chcący rozwijać tego typu działalność;

3) Zorganizowanie seminarium naukowego, pt.: „Social economy and social entrepreneurship - international experiences on the example of INN@SE project partners" w ramach Tygodnia Ekonomii Społecznej (19.11.2020);

4) Zorganizowanie debaty pt.: "Przedsiębiorczość społeczna i innowacje - razem czy osobno?" w ramach Małopolskiego Festiwalu Innowacji (21.06.2021).

Wyniki badań, o których mowa w p. 1, są obecnie wykorzystywane do przygotowania innowacyjnych narzędzi edukacyjnych. Zespół projektowy pracuje nad stworzeniem zestawu narzędzi (tzw. tool kit) bazującego na metodach edukacji pozaformalnej angażujących użytkowników, takich jak: odgrywanie ról, larpy edukacyjne (LARP - live action role-playing), myślenie projektowe (design thinking), gry w wersji cyfrowej. Narzędzia te będą dostępne dla wszystkich zainteresowanych osób poprzez stronę projektu.

Dalsze badania natomiast zmierzają do zdefiniowania modelu przedsiębiorczości społecznej młodzieży (INN@SE Youth Social Entrepreneurship model), opartego na identyfikacji i ocenie modeli biznesowych w kontekście ich zastosowania w sektorze ekonomii społecznej w celu zwiększenia efektywności ekonomicznej i skali wpływu społecznego sektora oraz budowania zrównoważonych modeli biznesowych przedsiębiorstw społecznych.

Ponadto, $\mathrm{w}$ projekcie wykorzystywane są metody service design i co-design, w celu stworzenia rekomendacji dla twórców polityki w zakresie wspierania przedsiębiorczości. $\mathrm{W}$ pierwszym etapie, $\mathrm{w}$ procesie tym

2 D. Murzyn, M. Czyżewska, I. Lupa-Wójcik, W. Maciejewski, Innovative Social Entrepreneurship with Youth Engagement. Needs Analysis in Poland, Italy, North Macedonia and Jordan, Wydawnictwo Naukowe Uniwersytetu Pedagogicznego, Kraków 2020. 
uczestniczyli młodzi ludzie (z 4 krajów: Polski, Włoch, Macedonii Północnej i Jordanii), poszukujący możliwości zawodowych i „początkujący" przedsiębiorcy jako potencjalni użytkownicy, którzy najlepiej wiedzą czego potrzebują. Prace prowadzone były przez międzynarodowe zespoły młodych ludzi i koordynowane przez wykładowców i studentów kierunku Service design z Uniwersytetu w Bolonii (w ramach seminarium: „Young Social Entrepreneur Challenge: design of services to stimulate innovative entrepreneurship with a social impact among young people" realizowanego w miesiącach wrzesień - grudzień 2020 r.). W drugim etapie działań stworzone $\mathrm{w}$ ten sposób koncepcje będą testowane na poziomie lokalnym w każdym z krajów partnerskich wśród podmiotów i interesariuszy, którzy zajmują się wspieraniem rozwoju przedsiębiorczości. W tym celu zorganizowane zostaną tzw. multi stakeholders tables a następnie przeprowadzone po 4 spotkania grup fokusowych w każdym kraju. Efektem finalnym tych prac będzie stworzenie rekomendacji dla twórców polityki (Policy Paper) odnośnie tego, jak można stymulować innowacyjną przedsiębiorczość, która będzie miała wpływ społeczny wśród młodych, aspirujących przedsiębiorców i młodych ludzi poszukujących możliwości zawodowych.

W ramach projektu zorganizowane zostaną także trzy wydarzenia multiplikacyjne („Innovathons” zgodne z metodologią hackathonu), w celu rozpowszechnienia wyników projektu, promowania ich wykorzystywania i angażowania młodych ludzi na poziomie lokalnym (w Krakowie, Bolonii i Skopje).

Zgodnie z intencją pomysłodawców projektu, opracowanie innowacyjnej strategii promocji zrównoważonych przedsiębiorstw społecznych, obejmującej metodologię, narzędzia, rekomendacje, podejście oparte na wzajemnej wymianie dobrych praktyk pomiędzy partnerami z krajów o różnym poziomie know-how przyczyni się do zwiększenia świadomości w zakresie przedsiębiorczości społecznej i jej dalszego rozwoju w Polsce i na świecie.

Więcej o projekcie: https://innose.up.krakow.pl 